\title{
Mutagenicity and antimutagenicity of six Brazilian Byrsonima species assessed by the Ames test
}

\author{
Lívia Greghi Espanha', Flávia Aparecida Resende ${ }^{1 *}$, José de Sousa Lima Neto², Paula Karina Boldrin', \\ Catarine Haidê Nogueira ${ }^{1}$, Mariana Santoro de Camargo ${ }^{1}$, Rone Aparecido De Grandis ${ }^{1}$, \\ Lourdes Campaner dos Santos ${ }^{2}$, Wagner Vilegas ${ }^{3}$ and Eliana Aparecida Varanda ${ }^{1}$
}

\begin{abstract}
Background: In various regions of Brazil, several species of the genus Byrsonima (Malpighiaceae) are widely used to treat gastrointestinal complications. This genus has about 150 species of shrubs and trees distributed over the entire Neotropical region. Various biological activities have been identified in these plants, especially antioxidant, antimicrobial and topical and systemic anti-inflammatory activities. The aim of this study was to investigate the mutagenicity and antimutagenicity of hydroalcoholic leaf extracts of six species of Byrsonima: $B$. verbascifolia, B. correifolia, B. coccolobifolia, B. ligustrifolia, B. fagifolia and B. intermedia by the Salmonella microsome assay (Ames test).
\end{abstract}

Methods: Mutagenic and antimutagenic activity was assessed by the Ames test, with the Salmonella typhimurium tester strains TA100, TA98, TA97a and TA102, with (+S9) and without (-S9) metabolization, by the preincubation method.

Results: Only B. coccolobifolia and B. ligustrifolia showed mutagenic activity. However, the extracts of B. verbascifolia, $B$. correifolia, B. fagifolia and B. intermedia were found to be strongly antimutagenic against at least one of the mutagens tested.

Conclusions: These results contribute to valuable data on the safe use of medicinal plants and their potential chemopreventive effects. Considering the excellent antimutagenic activities extracted from B. verbascifolia, B. correifolia, B. fagifolia and B. intermedia, these extracts are good candidate sources of chemopreventive agents. However, $B$. coccolobifolia and B. ligustrifolia showed mutagenic activity, suggesting caution in their use.

Keywords: Salmonella/microsome assay, Chemoprevention, Medicinal plants

\section{Background}

The use of medicinal plants in folk medicine is based on empirical knowledge gathered for centuries by diverse ethnic groups. This knowledge, based on daily experience and passed down from generation to generation, constitutes the origin of modern medicine $[1,2]$.

Byrsonima is a genus of Neotropical trees and shrubs known for yellow, cherry-sized fruits. In various regions of Brazil, several species of this genus are widely used in the treatment of gastrointestinal problems. Research has confirmed a number of different biological activities in

\footnotetext{
* Correspondence: flaviabiomed@yahoo.com.br

'Department of Biological Sciences, Faculty of Pharmaceutical Sciences of Araraquara, UNESP- São Paulo State University, Rodovia Araraquara-Jaú, km 1, 14801-902 Araraquara, São Paulo, Brazil

Full list of author information is available at the end of the article
}

these plants, especially antioxidant, antimicrobial and topical and systemic anti-inflammatory activities. Phytochemically, this genus has been noted for the presence of flavonoids and triterpenoids [3].

In previous studies, the methanolic $(\mathrm{MeOH})$ leaf extract of B. crassa showed mutagenic activity in the Ames test with Salmonella typhimurium strain TA98, without the metabolic activation system (S9), and amentoflavone, one of the metabolites isolated from the ethyl acetate fraction of this species, gave positive results for mutagenicity [4], while the $\mathrm{MeOH}$ extract of $B$. intermedia demonstrated signs of mutagenic activity in the Salmonella strains TA98 and TA100 [5].

To complement the studies with the genus Byrsonima, we also tested $\mathrm{MeOH}$ and chloroform extracts of B. basiloba for mutagenicity and antimutagenicity. No 
mutagenic activity was observed in either extract. However, both extracts showed antimutagenic activity against direct and indirect mutagens [6].

Considering the popular use of these plants, the risk of using medicinal extracts without detailed investigation and the valuable role of chemopreventive substances, the aim of this study was to assess the mutagenic activity of hydroalcoholic extracts of leaves of six Byrsonima species (B. verbascifolia, B. correifolia, B. coccolobifolia, B. ligustrifolia, B. fagifolia and B. intermedia) by the Ames test, and to identify protective activity in these species against the mutagenicity of the direct and indirect-acting mutagens, 4-nitro- $o$-phenylenediamine (NPD), mitomycin $\mathrm{C}(\mathrm{MMC})$, benzo[a]pyrene $(\mathrm{B}[\mathrm{a}] \mathrm{P})$ and aflatoxin $\mathrm{B}_{1}\left(\mathrm{AFB}_{1}\right)$.

\section{Methods}

\section{Chemicals}

Dimethylsulfoxide (DMSO), nicotinamide adenine dinucleotide phosphate sodium salt (NADP), D-glucose-6phosphate disodium salt, magnesium chloride, L-histidine monohydrate, D-biotin, sodium azide $\left(\mathrm{NaN}_{3}\right)$, 2-anthramine (2-AA), NPD, MMC, 2-aminofluorene (2-AF), B[a]P and $\mathrm{AFB}_{1}$ were purchased from Sigma Chemical Co (St. Louis, MO, USA). Oxoid Nutrient Broth No. 2 (Oxoid, England) was used as the bacterial culture medium. D-Glucose, magnesium sulfate, citric acid monohydrate, anhydrous dibasic potassium phosphate, sodium ammonium phosphate, monobasic sodium phosphate, dibasic sodium phosphate and sodium chloride were purchased from Merck (Whitehouse Station, NJ, USA).

\section{Plant material and extraction}

Aerial parts of each species were collected in the states of São Paulo, Tocantins and Piauí, Brazil, as reported in Table 1, which also has details of the voucher specimens.

The leaves were separated from the aerial parts, dried at $40^{\circ} \mathrm{C}$ to constant mass and then pulverized and stored in the dark, under cool, dry conditions, until used. Hydroalcoholic extracts were prepared in 7:3 (v/v) $\mathrm{EtOH} / \mathrm{H}_{2} \mathrm{O}$, in a stainless steel percolator $(20 \mathrm{~L})$. The solvent was added to the leaf powder and left standing for $2 \mathrm{~h}$, before packing the percolator, with a solvent: leaf powder ratio of 5:1 (w/w). The percolation was performed at a moderate flow rate of $2 \mathrm{~mL} / \mathrm{min} / \mathrm{kg}$. The solvent was eliminated from the extract in a rotatory evaporator (Heidolph Laborota 4001), equipped with low- pressure pump control with a Heidolph Rotavac Control valve. The residual water extract was dried in a Micro Module freeze-dryer (Savant Instruments Inc.). The dried extract was powdered and stored in amber bottles at $4^{\circ} \mathrm{C}$.

\section{Mutagenicity test}

Mutagenicity was assessed by the Ames test (Salmonella/microsome assay), with a preincubation for $20 \mathrm{~min}$, with $(+S 9)$ and without $(-S 9)$ metabolic activation. The Salmonella typhimurium tester strains, TA98, TA100, TA97a and TA102, were kindly provided by Dr. B.N. Ames (Berkeley, CA, USA) [7,8]. These strains were grown overnight from frozen cultures for $12-14 \mathrm{~h}$ in Oxoid $\mathrm{Nu}-$ trient Broth No. 2. The metabolic activation mixture (S9 fraction), prepared from livers of Sprague-Dawley rats treated with the polychlorinated biphenyl mixture Aroclor 1254 (500 mg/kg), was purchased from Molecular Toxicology Inc. (Boone, NC, USA) and freshly prepared before each test. The metabolic activation system consisted of 4\% S9 fraction, 1\% 0.4 $\mathrm{M} \mathrm{MgCl}_{2}, 1 \% 1.65 \mathrm{M} \mathrm{KCl}, 0.5 \% 1 \mathrm{M}$ D-glucose-6-phosphate disodium and 4\% 0.1 M NADP, $50 \% \quad 0.2 \mathrm{M}$ phosphate buffer and $39.5 \%$ sterile distilled water [8].

To assay mutagenic activity, five different concentrations of each dry extract $(0.20-16.7 \mathrm{mg} /$ plate for B. verbascifolia, 0.52-16.7 mg/plate for B. correifolia, $0.52-16.0 \mathrm{mg} / \mathrm{plate}$ for B. coccolobifolia, 0.02-18.0 mg/plate for B. ligustrifolia, 0.6-5.0 mg/plate for B. fagifolia and B. intermedia), dissolved in DMSO, were tested. The extract concentrations were selected on the basis of a preliminary toxicity test. In all subsequent assays, the upper limit of the dose range tested was either the highest non-toxic dose or the lowest toxic dose determined in this preliminary assay. Toxicity

Table 1 Plant material

\begin{tabular}{|c|c|c|c|}
\hline Species and identification authority & Voucher specimen number & Collection site & $\begin{array}{l}\text { Herbarium (where voucher } \\
\text { specimen is deposited) }\end{array}$ \\
\hline B. coccolobifolia Kunth. & 1397 & Itirapina, SP, Brazil & UNICAMP Herbarium \\
\hline B. intermedia A. Juss. & 1426 & Pratânia, SP, Brazil & UNICAMP Herbarium \\
\hline B. correifolia A. Juss. & 27151 & José de Freitas, PI, Brazil & $\begin{array}{l}\text { Graziella Barroso Herbarium, at } \\
\text { Federal University of Piauí }\end{array}$ \\
\hline B. fagifolia Nied. & 743 & Porto Nacional, TO, Brazil & $\begin{array}{l}\text { Herbarium of the Federal } \\
\text { University of Tocantins }\end{array}$ \\
\hline B. verbascifolia (L.) DC. & 481 & Porto Nacional, TO, Brazil & $\begin{array}{l}\text { Herbarium of the Federal } \\
\text { University of Tocantins }\end{array}$ \\
\hline B. ligustrifolia Mart. & 24164 & Pratânia, SP, Brazil & $\begin{array}{l}\text { Herbarium of São Paulo State } \\
\text { University, at Botucatu, SP. }\end{array}$ \\
\hline
\end{tabular}


was detected either as a reduction in the number of histidine revertants (His+) or as a thinning of the auxotrophic background lawn.

The various amounts of extracts to be tested, dissolved in DMSO, were added to $0.5 \mathrm{~mL}$ of $0.2 \mathrm{M}$ phosphate buffer or to $0.5 \mathrm{~mL}$ of $4 \% \mathrm{~S} 9$ mixture, plus $0.1 \mathrm{~mL}$ of bacterial culture and then incubated at $37^{\circ} \mathrm{C}$ for $20-30 \mathrm{~min}$. Thereafter, $2 \mathrm{ml}$ of top agar were added, and the mixture poured on to a plate containing minimal agar.

The plates were incubated at $37^{\circ} \mathrm{C}$ for $48 \mathrm{~h}$ and the His + revertant colonies were counted manually. All experiments were done in triplicate. The standard mutagens used as positive controls in experiments without the $\mathrm{S} 9$ mix were NPD $(10 \mu \mathrm{g} /$ plate $)$ for TA98 and TA97a, $\mathrm{NaN}_{3}$ (2.5 $\mu \mathrm{g} /$ plate) for TA100 and MMC (0.5 $\mu \mathrm{g} /$ plate) for TA102. In experiments with $\mathrm{S} 9$ activation, 2-AA $(1.5 \mu \mathrm{g} /$ plate) was used with TA98, TA97a and TA100 and 2-AF (5 $\mu \mathrm{g} /$ plate) with TA102. DMSO $(100 \mu \mathrm{L} /$ plate $)$ served as negative (solvent) control.

\section{Antimutagenicity test}

Only extracts considered non-mutagenic were subject to this test employing the method of preincubation in plates, developed by Maron and Ames [8]. Five different concentrations of extracts $(0.013-2.000 \mathrm{mg} / \mathrm{plate}$ for B. verbascifolia, 0.008-4.000 mg/plate for B. correifolia, 0.010-0.500 mg/plate for B. fagifolia and 0.007-0.250 mg/ plate for $B$. intermedia) were associated with known mutagens in tests with and without metabolic activation, using S. typhimurium tester strains TA98, TA100 and TA102. In the tests without metabolic activation, the mutagen NPD $(10.0 \mu \mathrm{g} /$ plate $)$ was used for TA98 and MMC $(0.5 \mu \mathrm{g} /$ plate $)$ for TA102, while in those with metabolic activation, $1.0 \mu \mathrm{g} /$ plate of $\mathrm{B}[\mathrm{a}] \mathrm{P}$ was used for TA98 and $0.5 \mu \mathrm{g} /$ plate of $\mathrm{AFB}_{1}$ for TA100. The extracts were mixed with $0.5 \mathrm{~mL}$ of $0.2 \mathrm{M}$ phosphate buffer, or $0.5 \mathrm{~mL}$ of $4 \%$ S9 mixture for metabolic activation, $0.1 \mathrm{~mL}$ of bacterial culture and the mutagen and incubated at $37^{\circ} \mathrm{C}$ for 20-30 min. After incubation, $2 \mathrm{~mL}$ of top agar was added, and the content of each tube was lightly homogenized and poured onto a plate of glucose minimal agar. After solidification of the top agar, the plates were incubated for $48 \mathrm{~h}$ at $37^{\circ} \mathrm{C}$, and the number of revertant colonies per plate was counted. The entire assay was performed in triplicate $[6,9]$.

\section{Data analysis}

The mutagenic activity results were analyzed with the statistical software package Salanal 1.0 (U.S. Environmental Protection Agency, Monitoring Systems Laboratory, Las Vegas, NV, from the Research Triangle Institute, RTP, NC, USA), adopting the model of Bernstein et al. [10]. The data (revertants/plate) were assessed by analysis of variance (ANOVA), followed by linear regression. The mutagenicity ratio (MR) was also calculated for each concentration tested; MR is the average number of revertants per test plate divided by the average number of revertants per negative (solvent) control plate. The sample was considered mutagenic when a dose-response relationship was detected and a two-fold increase in the number of revertants $(\mathrm{MR} \geq 2)$ was observed for at least one concentration [7].

The antimutagenic activity results were analyzed with the statistical software GraphPad Prism 5. The data (revertants/plate) were assessed by analysis of variance (one-way ANOVA), followed by Tukey's test. The antimutagenicity results were expressed as percent inhibition (the ability of the compounds to inhibit the action of the known mutagen), calculated as described by Tachino et al. [11]:

$$
\text { Inhibition }(\%)=100-[(\mathrm{T} / \mathrm{M}) \times 100]
$$

where $\mathrm{T}$ is the number of revertant colonies in a plate containing mutagen and compounds and $\mathrm{M}$ is the number of revertant colonies in a plate containing the mutagen alone.

Results were interpreted as no antimutagenic effect when the inhibition was lower than $25 \%$, a moderate effect for a value between $25 \%$ and $40 \%$ and strong antimutagenicity for values greater than $40 \%[9,12]$.

Cell viability was also determined in each antimutagenesis experiment, to assess the potential bactericidal effect of the mutagens and associations. A sample was considered bactericidal when the number of viable bacterial cells was less than $60 \%$ of that observed in the negative control $[6,13]$.

\section{Results}

\section{Mutagenicity test}

Table 2 shows the mean number of revertants/plate (M), the standard deviation (SD) and the mutagenic ratio (MR) after the treatments with the six extracts, observed in $S$. typhimurium strains TA98, TA100, TA97a and TA102, in the presence $(+\mathrm{S} 9)$ and absence $(-\mathrm{S} 9)$ of metabolic activation. The results showed that only $B$. coccolobifolia and $B$. ligustrifolia extracts induced an increase in the number of revertant colonies relative to the negative control, indicating mutagenic activity. B. coccolobifolia, in the absence of S9, showed activity in the strain TA98, with a doseresponse relationship reaching a mutagenic ratio of 2.8 . In the presence of S9, in the same strain, at all concentrations tested, this extract reached a mutagenic ratio higher than 2.0. B. ligustrifolia, in TA98 without S9, reached a mutagenic ratio of 2.0 at the two highest concentrations tested. None of the other species extracts induced twofold or greater increase in the mean number of revertants relative to the negative control group, in the presence or absence of S9. 
Table 2 Mutagenic activity expressed as mean number of revertants/plate \pm standard deviation and mutagenicity ratio (in brackets) of hydroalcoholic leaf extracts of six Byrsonima species

\begin{tabular}{|c|c|c|c|c|c|c|c|c|c|c|c|}
\hline \multirow[t]{2}{*}{ Treatment (mg/plate) } & \multicolumn{2}{|c|}{ TA98 } & \multirow[t]{2}{*}{$\begin{array}{l}\text { Treatment } \\
\text { (mg/plate) }\end{array}$} & \multicolumn{2}{|c|}{ TA100 } & \multirow{2}{*}{\multicolumn{2}{|c|}{$\begin{array}{r}\begin{array}{r}\text { Treatment } \\
\text { (mg/plate) }\end{array} \\
\text { - S9 }\end{array}$}} & \multirow{2}{*}{$\begin{array}{l}\text { TA97a } \\
+ \text { S9 }\end{array}$} & \multirow[t]{2}{*}{$\begin{array}{l}\text { Treatment } \\
\text { (mg/plate) }\end{array}$} & \multicolumn{2}{|c|}{ TA102 } \\
\hline & -59 & +59 & & -59 & +59 & & & & & -59 & +59 \\
\hline \multicolumn{12}{|l|}{ B. verbascifolia } \\
\hline $0.0^{\mathrm{a}}$ & $17 \pm 4$ & $68 \pm 1$ & $0.0^{\mathrm{a}}$ & $113 \pm 16$ & $114 \pm 11$ & $0.0^{\mathrm{a}}$ & $81 \pm 6$ & $121 \pm 20$ & $0.0^{\mathrm{a}}$ & $381 \pm 43$ & $341 \pm 34$ \\
\hline 2.1 & $15 \pm 3(0.9)$ & $67 \pm 2(1.0)$ & 0.4 & $91 \pm 8(0.8)$ & $121 \pm 12(1.1)$ & 0.2 & $78 \pm 3(1.0)$ & $137 \pm 16(1.1)$ & 0.4 & $369 \pm 3(1.0)$ & $387 \pm 20(1.1)$ \\
\hline 4.2 & $24 \pm 6(1.4)$ & $75 \pm 5(1.1)$ & 0.7 & $107 \pm 20(1.0)$ & $124 \pm 10(1.1)$ & 0.4 & $97 \pm 2(1.2)$ & $140 \pm 10(1.2)$ & 0.7 & $305 \pm 16(0.8)$ & $445 \pm 32(1.3)$ \\
\hline 8.3 & $18 \pm 6(1.0)$ & $81 \pm 3(1.2)$ & 1.5 & $106 \pm 2(0.9)$ & $99 \pm 4(0.9)$ & 0.8 & $117 \pm 2(1.4)$ & $146 \pm 7(1.2)$ & 1.5 & $368 \pm 36(1.0)$ & $353 \pm 29(1.0)$ \\
\hline 12.5 & $23 \pm 3(1.3)$ & $61 \pm 4(0.9)$ & 2.2 & $105 \pm 4(0.9)$ & $104 \pm 5(0.9)$ & 1.1 & $109 \pm 6(1.3)$ & $166 \pm 12(1.4)$ & 2.2 & $322 \pm 45(0.9)$ & $344 \pm 45(1.0)$ \\
\hline 16.7 & $29 \pm 12(1.7)$ & $50 \pm 1(0.7)$ & 3.0 & $110 \pm 9(1.0)$ & $93 \pm 3(0.8)$ & 1.6 & $94 \pm 5(1.2)$ & $169 \pm 39(1.4)$ & 3.0 & $373 \pm 11(1.0)$ & $350 \pm 27(1.0)$ \\
\hline$C+$ & $720 \pm 28^{b}$ & $500 \pm 32^{c}$ & $C+$ & $1375 \pm 35^{d}$ & $1387 \pm 37^{c}$ & $\mathrm{C}+$ & $1115 \pm 25^{\mathrm{b}}$ & $1450 \pm 70^{c}$ & $C+$ & $1468 \pm 53^{e}$ & $1403 \pm 33^{f}$ \\
\hline \multicolumn{12}{|l|}{ B. correifolia } \\
\hline $0.0^{\mathrm{a}}$ & $20 \pm 4$ & $68 \pm 1$ & $0.0^{\mathrm{a}}$ & $93 \pm 6$ & $114 \pm 11$ & $0.0^{\mathrm{a}}$ & $172 \pm 2$ & $99 \pm 1$ & $0.0^{\mathrm{a}}$ & $352 \pm 30$ & $435 \pm 43$ \\
\hline 2.1 & $16 \pm 3(0.8)$ & $86 \pm 6(1.3)$ & 0.5 & $73 \pm 3(0.8)$ & $103 \pm 5(0.9)$ & 0.5 & $185 \pm 6(1.1)$ & $85 \pm 4(0.9)$ & 0.5 & $397 \pm 11(1.1)$ & $608 \pm 45(1.4)$ \\
\hline 4.2 & $18 \pm 2(0.9)$ & $80 \pm 3(1.2)$ & 1.0 & $90 \pm 10(1.0)$ & $106 \pm 8(0.9)$ & 1.0 & $165 \pm 11(1.0)$ & $123 \pm 11(1.3)$ & 1.0 & $386 \pm 33(1.1)$ & $564 \pm 35(1.3)$ \\
\hline 8.3 & $27 \pm 3(1.3)$ & $66 \pm 6(1.0)$ & 2.1 & $93 \pm 8(1.0)$ & $96 \pm 9(0.8)$ & 2.1 & $166 \pm 18(1.0)$ & $135 \pm 4(1.4)$ & 2.1 & $413 \pm 16(1.2)$ & $484 \pm 33(1.1)$ \\
\hline 12.5 & $37 \pm 10(1.8)$ & $62 \pm 3(0.9)$ & 3.1 & $94 \pm 11(1.0)$ & $115 \pm 12(1.0)$ & 3.1 & $186 \pm 5(1.1)$ & $110 \pm 4(1.1)$ & 3.1 & $333 \pm 50(1.0)$ & $354 \pm 38(0.8)$ \\
\hline 16.7 & $31 \pm 6(1.5)$ & $60 \pm 9(0.9)$ & 4.2 & $65 \pm 6(0.7)$ & $94 \pm 4(0.8)$ & 4.2 & $143 \pm 10(0.8)$ & $134 \pm 5(1.4)$ & 4.2 & $285 \pm 21(0.8)$ & $322 \pm 32(0.7)$ \\
\hline$C+$ & $730 \pm 28^{b}$ & $500 \pm 32^{c}$ & $C+$ & $1250 \pm 35^{d}$ & $700 \pm 37^{c}$ & $\mathrm{C}+$ & $950 \pm 25^{b}$ & $1450 \pm 70^{c}$ & $\mathrm{C}+$ & $1468 \pm 53^{e}$ & $1403 \pm 33^{f}$ \\
\hline \multicolumn{12}{|l|}{ B. coccolobifolia } \\
\hline $0.0^{\mathrm{a}}$ & $37 \pm 8$ & $24 \pm 4$ & $0.0^{\mathrm{a}}$ & $112 \pm 13$ & $92 \pm 9$ & $0.0^{\mathrm{a}}$ & $172 \pm 2$ & $123 \pm 15$ & $0.0^{\mathrm{a}}$ & $406 \pm 11$ & $341 \pm 34$ \\
\hline 2.0 & $56 \pm 3^{*}(1.5)$ & $56 \pm 6^{* *}(2.3)$ & 0.5 & $115 \pm 10(1.0)$ & $102 \pm 12(1.1)$ & 0.5 & $129 \pm 15(0.7)$ & $144 \pm 11(1.2)$ & 0.5 & $345 \pm 8(0.9)$ & $386 \pm 17(1.1)$ \\
\hline 4.0 & $61 \pm 8^{*}(1.7)$ & $51 \pm 1 * *(2.1)$ & 1.0 & $135 \pm 18(1.2)$ & $115 \pm 7(1.3)$ & 1.0 & $145 \pm 10(0.8)$ & $163 \pm 11(1.3)$ & 1.0 & $338 \pm 13(0.8)$ & $366 \pm 12(1.1)$ \\
\hline 8.0 & $70 \pm 9^{*}(1.9)$ & $67 \pm 13^{*}(2.8)$ & 2.1 & $154 \pm 25$ & $110 \pm 11(1.2)$ & 2.1 & $175 \pm 15(1.0)$ & $208 \pm 29^{*}(1.7)$ & 2.1 & $350 \pm 23(0.9)$ & $330 \pm 24(1.0)$ \\
\hline 12.0 & $102 \pm 10^{* *}(2.8)$ & $64 \pm 9^{* *}(2.6)$ & 3.1 & $170 \pm 14(1.5)$ & $108 \pm 8(1.2)$ & 3.1 & $214 \pm 5(1.2)$ & $215 \pm 13^{* *}(1.8)$ & 3.1 & $355 \pm 13(0.9)$ & $297 \pm 8(0.9)$ \\
\hline 16.0 & $67 \pm 10^{*}(1.9)$ & $63 \pm 13^{*}(2.6)$ & 4.2 & $143 \pm 27(1.3)$ & $115 \pm 18(1.3)$ & 4.2 & $190 \pm 7(1.1)$ & $237 \pm 34^{*}(1.9)$ & 4.2 & $358 \pm 10(0.9)$ & $261 \pm 2(0.8)$ \\
\hline $\mathrm{C}_{+}$ & $531 \pm 28^{b}$ & $500 \pm 30^{c}$ & $\mathrm{C}+$ & $1375 \pm 35^{d}$ & $700 \pm 38^{c}$ & $\mathrm{C}+$ & $950 \pm 25^{b}$ & $700 \pm 30^{c}$ & $\mathrm{C}+$ & $1143 \pm 28^{e}$ & $1403 \pm 33^{f}$ \\
\hline
\end{tabular}


Table 2 Mutagenic activity expressed as mean number of revertants/plate \pm standard deviation and mutagenicity ratio (in brackets) of hydroalcoholic leaf extracts of six Byrsonima species (Continued)

\begin{tabular}{|c|c|c|c|c|c|c|c|c|c|c|c|}
\hline \multicolumn{12}{|l|}{ B. ligustrifolia } \\
\hline $0.0^{\mathrm{a}}$ & $18 \pm 3$ & $24 \pm 4$ & $0.0^{\mathrm{a}}$ & $210 \pm 33$ & $87 \pm 15$ & $0.0^{\mathrm{a}}$ & $110 \pm 9$ & $115 \pm 1$ & $0.0^{\mathrm{a}}$ & $262 \pm 25$ & $407 \pm 30$ \\
\hline 2.2 & $21 \pm 1(1.2)$ & $22 \pm 5(0.9)$ & 0.08 & $226 \pm 13(1.1)$ & $114 \pm 13(1.3)$ & 0.16 & $106 \pm 5(1.0)$ & $132 \pm 12(1.2)$ & 0.02 & $330 \pm 16(1.3)$ & $379 \pm 45(0.9)$ \\
\hline 4.0 & $22 \pm 1(1.3)$ & $27 \pm 8(1.1)$ & 0.16 & $211 \pm 12(1.0)$ & $98 \pm 6(1.1)$ & 0.31 & $109 \pm 8(1.0)$ & $136 \pm 8(1.2)$ & 0.04 & $232 \pm 2(0.9)$ & $382 \pm 21(0.9)$ \\
\hline 9.0 & $20 \pm 2(1.1)$ & $38 \pm 7(1.6)$ & 0.31 & $224 \pm 37(1.1)$ & $90 \pm 9(1.0)$ & 0.62 & $127 \pm 7(1.2)$ & $132 \pm 19(1.2)$ & 0.08 & $244 \pm 25(0.9)$ & $411 \pm 20(1.0)$ \\
\hline 13.5 & $35 \pm 6^{*}(2.0)$ & $34 \pm 9(1.4)$ & 0.47 & $227 \pm 24(1.1)$ & $94 \pm 3(1.1)$ & 0.94 & $90 \pm 6(0.8)$ & $145 \pm 17(1.3)$ & 0.12 & $243 \pm 22(0.9)$ & $395 \pm 12(1.0)$ \\
\hline 18.0 & $36 \pm 5^{*}(2.0)$ & $32 \pm 2(1.3)$ & 0.62 & $209 \pm 11(1.0)$ & $93 \pm 16(1.1)$ & 1.25 & $121 \pm 1(1.1)$ & $133 \pm 4(1.2)$ & 0.16 & $258 \pm 11(1.0)$ & $328 \pm 15(0.8)$ \\
\hline$C+$ & $300 \pm 12^{b}$ & $227 \pm 16^{c}$ & $\mathrm{C}+$ & $919 \pm 17^{d}$ & $987 \pm 32^{c}$ & $\mathrm{C}+$ & $1110 \pm 32^{b}$ & $1036 \pm 41^{c}$ & $\mathrm{C}+$ & $1349 \pm 45^{e}$ & $1464 \pm 43^{f}$ \\
\hline \multicolumn{12}{|l|}{ B. fagifolia } \\
\hline $0.0^{\mathrm{a}}$ & $23 \pm 2$ & $22 \pm 3$ & $0.0^{\mathrm{a}}$ & $124 \pm 10$ & $100 \pm 7$ & $0.0^{\mathrm{a}}$ & $154 \pm 10$ & $164 \pm 23$ & $0.0^{\mathrm{a}}$ & $321 \pm 39$ & $300 \pm 58$ \\
\hline 0.6 & $26 \pm 1(1.1)$ & $28 \pm 4(1.3)$ & 0.6 & $146 \pm 13(1.2)$ & $121 \pm 9(1.2)$ & 0.6 & $190 \pm 16(1.2)$ & $175 \pm 21(1.1)$ & 0.6 & $396 \pm 38(1.2)$ & $269 \pm 67(0.9)$ \\
\hline 1.2 & $23 \pm 3(1.0)$ & $29 \pm 2(1.3)$ & 1.2 & $127 \pm 5(1.0)$ & $115 \pm 3(1.2)$ & 1.2 & $172 \pm 7(1.1)$ & $176 \pm 25(1.1)$ & 1.2 & $385 \pm 31(1.2)$ & $332 \pm 23(1.1)$ \\
\hline 2.5 & $27 \pm 2(1.2)$ & $24 \pm 8(1.1)$ & 2.5 & $125 \pm 18(1.0)$ & $126 \pm 9(1.3)$ & 2.5 & $171 \pm 16(1.1)$ & $194 \pm 11(1.2)$ & 2.5 & $356 \pm 25(1.1)$ & $320 \pm 54(1.1)$ \\
\hline 3.7 & $38 \pm 8^{*}(1.7)$ & $25 \pm 2(1.1)$ & 3.7 & $139 \pm 23(1.1)$ & $117 \pm 24(1.2)$ & 3.7 & $176 \pm 12(1.1)$ & $184 \pm 6(1.1)$ & 3.7 & $261 \pm 47(0.8)$ & $273 \pm 69(0.9)$ \\
\hline 5.0 & $38 \pm 6^{*}(1.7)$ & $29 \pm 4(1.3)$ & 5.0 & $155 \pm 5(1.3)$ & $107 \pm 10(1.1)$ & 5.0 & $172 \pm 11(1.1)$ & $176 \pm 20(1.1)$ & 5.0 & $277 \pm 64(0.9)$ & $221 \pm 43(0.7)$ \\
\hline $\mathrm{C}_{+}$ & $947 \pm 88^{b}$ & $767 \pm 115^{c}$ & $C_{+}$ & $1682 \pm 98^{d}$ & $1956 \pm 78^{c}$ & $\mathrm{C}+$ & $1766 \pm 49^{b}$ & $1989 \pm 89^{c}$ & $\mathrm{C}+$ & $2656 \pm 60^{e}$ & $2932 \pm 97^{f}$ \\
\hline \multicolumn{12}{|l|}{ B. intermedia } \\
\hline $0.0^{\mathrm{a}}$ & $22 \pm 5$ & $21 \pm 8$ & $0.0^{\mathrm{a}}$ & $151 \pm 14$ & $151 \pm 4$ & $0.0^{\mathrm{a}}$ & $176 \pm 10$ & $249 \pm 22$ & $0.0^{\mathrm{a}}$ & $303 \pm 99$ & $396 \pm 12$ \\
\hline 0.6 & $23 \pm 3(1.0)$ & $21 \pm 7(1.0)$ & 0.6 & $162 \pm 7(1.1)$ & $169 \pm 12(1.1)$ & 0.6 & $187 \pm 25$ & $304 \pm 28(1.2)$ & 0.6 & $274 \pm 36(0.9)$ & $427 \pm 66(1.1)$ \\
\hline 1.2 & $28 \pm 4(1.3)$ & $21 \pm 3(1.0)$ & 1.2 & $165 \pm 5(1.1)$ & $157 \pm 15(1.0)$ & 1.2 & $228 \pm 16(1.3)$ & $315 \pm 7(1.3)$ & 1.2 & $243 \pm 19(0.8)$ & $380 \pm 28(1.0)$ \\
\hline 2.5 & $30 \pm 3(1.4)$ & $17 \pm 6(0.8)$ & 2.5 & $142 \pm 10(0.9)$ & $160 \pm 5(1.1)$ & 2.5 & $201 \pm 26(1.1)$ & $261 \pm 18(1.0)$ & 2.5 & $285 \pm 64(0.9)$ & $401 \pm 60(1.0)$ \\
\hline 3.7 & $28 \pm 1$ (1.3) & $25 \pm 8(1.2)$ & 3.7 & $155 \pm 18(1.0)$ & $150 \pm 4(1.0)$ & 3.7 & $199 \pm 7(1.1)$ & $270 \pm 19(1.1)$ & 3.7 & $345 \pm 61(1.1)$ & $351 \pm 63(0.9)$ \\
\hline 5.0 & $35 \pm 5^{*}(1.6)$ & $17 \pm 2(0.8)$ & 5.0 & $163 \pm 8(1.1)$ & $140 \pm 7(0.9)$ & 5.0 & $176 \pm 23(1.0)$ & $261 \pm 13(1.0)$ & 5.0 & $302 \pm 53(1.0)$ & $281 \pm 72(0.7)$ \\
\hline$C+$ & $872 \pm 67^{b}$ & $736 \pm 79^{c}$ & $C+$ & $1512 \pm 64^{d}$ & $1500 \pm 88^{c}$ & $\mathrm{C}+$ & $1196 \pm 52^{b}$ & $1217 \pm 69^{c}$ & $\mathrm{C}+$ & $2539 \pm 187^{e}$ & $2114 \pm 162^{f}$ \\
\hline
\end{tabular}

$5 \mu \mathrm{g} /$ plate. ${ }^{*} \mathrm{p}<0.05 ;{ }^{* *} \mathrm{p}<0.01$ (ANOVA). 


\section{Antimutagenicity test}

The antimutagenic effect of each extract was assessed from the mean number of revertants/plate, the standard deviation (SD) and the percent inhibition (\% I) of the mutagenic activity of $\mathrm{NPD}, \mathrm{MMC} \mathrm{AFB}_{1}$ and $\mathrm{B}[\mathrm{a}] \mathrm{P}$ on treatment with the five concentrations of the extract. The results are displayed in Table 3. B. verbascifolia extract can be considered a strong antimutagen against NPD, as it showed more than $40 \%$ inhibition at two of the concentrations tested. When tested with MMC, this extract did not show antimutagenic activity; however, with $\mathrm{AFB}_{1}$, all five concentrations tested showed more than $40 \%$ inhibition, and concentrations in the range of $0.25-2 \mathrm{mg} /$ plate achieved $91 \%$ inhibition, making the extract a very strong antimutagen. Against $\mathrm{B}[\mathrm{a}] \mathrm{P}$, the five tested concentrations of the extract of $B$. verbascifolia also showed more than $40 \%$ inhibition and the highest concentration attained $82 \%$, ranking it as strongly antimutagenic.

B. correifolia extract also showed strong antimutagenic activity against NPD, as it induced more than $40 \%$ inhibition at four of the five concentrations tested. However, the extract was not antimutagenic against MMC. When mixed with $\mathrm{AFB}_{1}$, all five tested concentrations of the extract showed inhibition exceeding $40 \%$, reaching $80 \%$ at one concentration. Thus, B. correifolia had strong antimutagenic activity against this agent. Associated with $\mathrm{B}[\mathrm{a}] \mathrm{P}$, all five concentrations of the extract of $B$. correifolia tested showed inhibition of revertants around $80 \%$, reaching $83 \%$ at one concentration, representing very high antimutagenicity. Although B. correifolia was not found to be antimutagenic against MMC, it demonstrated a potential for significant reduction in the numbers of revertants.

Extract of B. fagifolia and B. intermedia can be described as moderately antimutagenic against NPD, as they inhibited 36\% and 30\% of revertants, respectively. Against $\mathrm{MMC}$, these extracts showed no antimutagenic activity. When combined with $\mathrm{AFB}_{1}$, these extracts showed 36\% and $32 \%$ inhibition, respectively, and can be considered moderately antimutagenic. When mixed with $\mathrm{B}[\mathrm{a}] \mathrm{P}$, the two extracts induced inhibition greater than $40 \%$, reaching $76 \%$ and $77 \%$, respectively, and ranking them as strongly antimutagenic.

\section{Discussion}

In Brazil, plants of the genus Byrsonima (Malpighiaceae) represent a rich source of catechin and epicatechin derivatives and are used in folk medicine for the treatment of gastric ulcers, inflammation, skin infections, fever and asthma. They are popularly known as "murici-vermelho" or "murici-cascudo" and grow wild in the cerrado (savannah-like) vegetation of Brazil. Byrsonima species have been scientifically proven to possess several pharmacological properties, such as antiulcerogenic, mutagenic and antimicrobial activity [14].
The results of this study demonstrate an absence of any mutagenic activity in leaf extracts of $B$. verbascifolia, B. correifolia, B. fagifolia and B. intermedia, at all the concentrations tested on the four S. typhimurium strains, since the number of revertant colonies observed on each test plate was less than twice that in the negative control [7]. However, B. coccolobifolia extract doubled the number of revertant colonies in strain TA98, both in the presence and in the absence of metabolic activation, suggesting an ability to cause frameshift mutations, before and even after being metabolized. In strain TA97a, the dose-response for B. coccolobifolia went up to a mutagenicity ratio of 1.9 , giving evidence of mutagenicity. B. ligustrifolia also doubled the number of revertant colonies in strain TA98 in the absence of metabolic activation and can be considered an inducer of frameshift mutations.

In a previous study, we showed that a $\mathrm{MeOH}$ extract of B. crassa exhibited mutagenic activity in the Ames test. The following compounds were isolated from the acetate fraction: quercetin-3-O- $\beta{ }_{-}{ }^{-}$-galactopyranoside, quercetin3-O- $\alpha-{ }_{\mathrm{L}}$-arabinopyranoside, amentoflavone, methyl gallate and $(+)$-catechin. Among these, only amentoflavone exhibited positive mutagenicity. Therefore, this compound contributes to the mutagenic activity observed in the $\mathrm{MeOH}$ extract [4].

In another study, $\mathrm{MeOH}$, hydromethanol and chloroform extracts of $B$. intermedia were assessed for mutagenicity by the Ames test and mutagenic activity was not positively identified, in any extract, but the $\mathrm{MeOH}$ extract showed signs of mutagenicity to the strains TA98 $(+$ S9,-S9) and TA100 (-S9). The values of the MR were close to 2 , and the dose-response effect was significant. Phytochemical analysis of the $\mathrm{MeOH}$ extract furnished (+)-catechin, (-)-epicatechin, quercetin-3-O$\beta_{-}{ }^{-}$-galactopyranoside, methyl gallate, gallic acid, quercetin3-O- $\alpha{ }_{-}-$-arabinopyranoside, amentoflavone, quercetin, quercetin-3-O-(2"-O-galloyl)- $\beta$-galactopyranoside and quercetin-3-O-(2"-O-galloyl)- $\alpha$-arabinopyranoside [5].

Comparing the compounds in the $\mathrm{MeOH}$ extracts of B. intermedia with those from B. crassa [15], similar profiles were observed, but a difference was seen in the flavonol concentration and the difference in the amentoflavone content explained the results obtained. In $B$. crassa, mutagenic activity was observed and the main compound of the extract responsible for this effect was amentoflavone [4]. In B. intermedia, this biflavonol is also present, but in smaller amounts, explaining the signs of mutagenic activity obtained in the assays with Salmonella [5].

Quercetin is a compound that is always present in Byrsonima extracts [4-6]. It is a flavonoid known for its mutagenic potential. Resende et al. [16] showed that quercetin is highly mutagenic in TA98, TA100 and TA102. This compound has been observed to induce a mutation 
Table 3 Antimutagenic activity expressed as mean number of revertants/plate (M) \pm standard deviation (SD) and degree of growth inhibition of revertants (\%l), in combinations of four Byrsonima species hydroalcoholic extracts with direct and indirect mutagens

\begin{tabular}{|c|c|c|c|c|c|c|c|c|}
\hline \multirow[t]{2}{*}{$\begin{array}{c}\text { Mutagens (M) } \\
\text { Strains }\end{array}$} & \multicolumn{2}{|c|}{$\begin{array}{c}\text { NPD }^{\mathrm{b}} \\
\text { TA } 98 \text { (-S9) }\end{array}$} & \multicolumn{2}{|c|}{$\begin{array}{c}M M^{c} \\
\text { TA } 102(-S 9)\end{array}$} & \multicolumn{2}{|c|}{$\begin{array}{c}\mathrm{AFB}_{1}^{\mathrm{d}} \\
\mathrm{TA} 100(+\mathrm{S} 9)\end{array}$} & \multicolumn{2}{|c|}{$\begin{array}{c}\mathrm{B}[\mathrm{a}] \mathrm{P}^{\mathrm{e}} \\
\mathrm{TA} 98 \text { (+S9) }\end{array}$} \\
\hline & Treatment (mg/plate) & $\mathrm{M} \pm \mathrm{SD}$ and $(\% \mathrm{l})$ & Treatment (mg/plate) & $\mathrm{M} \pm \mathrm{SD}$ and $(\% \mathrm{l})$ & Treatment (mg/plate) & $\mathrm{M} \pm \mathrm{SD}$ and $(\% \mathrm{l})$ & Treatment (mg/plate) & $\mathrm{M} \pm \mathrm{SD}$ and $(\% \mathrm{I})$ \\
\hline \multicolumn{9}{|l|}{ B. verbascifolia } \\
\hline & $0^{\mathrm{a}}$ & $18 \pm 4$ & $0^{\mathrm{a}}$ & $487 \pm 81$ & $0^{\mathrm{a}}$ & $114 \pm 6$ & $0^{\mathrm{a}}$ & $36 \pm 5$ \\
\hline & $0.013+M^{b}$ & $483 \pm 40^{* *}(45)$ & $0.094+M^{c}$ & $1502 \pm 138(6)$ & $0.125+M^{d}$ & $213 \pm 7^{* * *}(85)$ & $0.049+M^{e}$ & $102 \pm 24^{* * *}(44)$ \\
\hline & $0.025+M^{b}$ & $454 \pm 60^{* * *}(48)$ & $0.188+M^{c}$ & $1296 \pm 24(19)$ & $0.250+M^{d}$ & $131 \pm 27^{* * *}(91)$ & $0.098+M^{e}$ & $78 \pm 6^{* * *}(57)$ \\
\hline & $0.050+M^{b}$ & $550 \pm 41 * *(37)$ & $0.375+M^{c}$ & $1366 \pm 21(15)$ & $0.500+M^{d}$ & $125 \pm 16^{* * *}(91)$ & $0.195+M^{e}$ & $85 \pm 9^{* * *}(54)$ \\
\hline & $0.100+M^{b}$ & $628 \pm 138^{*}(28)$ & $0.750+M^{c}$ & $1380 \pm 4(14)$ & $1.000+M^{d}$ & $132 \pm 13^{* * *}(91)$ & $0.390+M^{e}$ & $41 \pm 5^{* * *}(78)$ \\
\hline & $0.200+M^{b}$ & $1001 \pm 137$ & $1.500+M^{c}$ & $1381 \pm 58(14)$ & $2.000+M^{d}$ & $132 \pm 24^{* * *}(91)$ & $0.780+M^{e}$ & $34 \pm 7^{* * *}(82)$ \\
\hline & $M^{b}$ & $876 \pm 30$ & $M^{c}$ & $1601 \pm 226$ & $M^{d}$ & $1399 \pm 34$ & $M^{e}$ & $184 \pm 8$ \\
\hline \multicolumn{9}{|l|}{ B. correifolia } \\
\hline & $0^{\mathrm{a}}$ & $18 \pm 4$ & $0^{\mathrm{a}}$ & $464 \pm 48$ & $0^{\mathrm{a}}$ & $104 \pm 15$ & $0^{\mathrm{a}}$ & $36 \pm 5$ \\
\hline & $0.013+M^{b}$ & $440 \pm 57^{* * *}(50)$ & $0.031+M^{c}$ & $1208 \pm 15(15)$ & $0.008+M^{d}$ & $353 \pm 59^{* * *}(60)$ & $0.250+M^{e}$ & $34 \pm 6^{* * *}(82)$ \\
\hline & $0.025+M^{b}$ & $426 \pm 2^{* * *}(51)$ & $0.063+M^{c}$ & $1126 \pm 66^{*}(20)$ & $0.016+M^{d}$ & $248 \pm 38^{* * *}(72)$ & $0.500+M^{e}$ & $31 \pm 6^{* * *}(83)$ \\
\hline & $0.050+M^{b}$ & $497 \pm 39^{* * *}(43)$ & $0.125+M^{c}$ & $1152 \pm 74^{*}(19)$ & $0.031+M^{d}$ & $370 \pm 49^{* * *}(58)$ & $1.000+M^{e}$ & $32 \pm 6^{* * *}(82)$ \\
\hline & $0.100+M^{b}$ & $593 \pm 20^{* * *}(32)$ & $0.250+M^{c}$ & $1205 \pm 52(15)$ & $0.063+M^{d}$ & $180 \pm 57^{* * *}(80)$ & $2.000+M^{e}$ & $31 \pm 5^{* * *}(83)$ \\
\hline & $0.200+M^{b}$ & $521 \pm 61^{* * *}(41)$ & $0.500+M^{c}$ & $1129 \pm 146^{*}(20)$ & $0.125+M^{d}$ & $206 \pm 46^{* * *}(77)$ & $4.000+M^{e}$ & $39 \pm 3^{* * *}(79)$ \\
\hline & $M^{b}$ & $876 \pm 30$ & $M^{c}$ & $1414 \pm 61$ & $M^{d}$ & $883 \pm 80$ & $M^{e}$ & $184 \pm 8$ \\
\hline \multicolumn{9}{|l|}{ B. fagifolia } \\
\hline & $0^{\mathrm{a}}$ & $45 \pm 8$ & $0^{a}$ & $355 \pm 36$ & $0^{\mathrm{a}}$ & $94 \pm 12$ & $0^{a}$ & $19 \pm 7$ \\
\hline & $0.030+M^{b}$ & $705 \pm 72(7)$ & $0.010+M^{c}$ & $1579 \pm 94$ & $0.030+M^{d}$ & $976 \pm 38(8)$ & $0.030+M^{e}$ & $378 \pm 49^{* * *}(41)$ \\
\hline & $0.060+M^{b}$ & $612 \pm 43(19)$ & $0.030+M^{c}$ & $1395 \pm 70$ & $0.060+M^{d}$ & $915 \pm 44(14)$ & $0.060+M^{e}$ & $405 \pm 51^{* * *}(37)$ \\
\hline & $0.120+M^{b}$ & $623 \pm 38(17)$ & $0.060+M^{c}$ & $1499 \pm 89$ & $0.120+M^{d}$ & $739 \pm 40^{* * *}(31)$ & $0.120+M^{e}$ & $332 \pm 35^{* * *}(48)$ \\
\hline & $0.250+M^{b}$ & $593 \pm 51(21)$ & $0.120+M^{c}$ & $1432 \pm 79$ & $0.250+M^{d}$ & $781 \pm 52^{* *}(27)$ & $0.250+M^{e}$ & $268 \pm 43^{* * *}(58)$ \\
\hline & $0.500+M^{b}$ & $483 \pm 40 *(36)$ & $0.250+M^{c}$ & $1440 \pm 65$ & $0.500+M^{d}$ & $680 \pm 36^{* * *}(36)$ & $0.500+M^{e}$ & $157 \pm 29^{* * *}(76)$ \\
\hline & $M^{b}$ & $755 \pm 89$ & $M^{c}$ & $1251 \pm 82$ & $M^{d}$ & $1064 \pm 101$ & $M^{e}$ & $640 \pm 49$ \\
\hline
\end{tabular}


Table 3 Antimutagenic activity expressed as mean number of revertants/plate (M) \pm standard deviation (SD) and degree of growth inhibition of revertants (\%l), in combinations of four Byrsonima species hydroalcoholic extracts with direct and indirect mutagens (Continued)

\begin{tabular}{|c|c|c|c|c|c|c|c|c|}
\hline \\
\hline \multicolumn{9}{|l|}{ B. intermedia } \\
\hline & $0.010+M^{b}$ & $677 \pm 67^{*}(24)$ & $0.007+M^{c}$ & $1593 \pm 71$ & $0.010+M^{d}$ & $981 \pm 61(8)$ & $0.010+M^{e}$ & $338 \pm 37^{* * *}(47)$ \\
\hline & $0.030+M^{b}$ & $679 \pm 61^{*}(24)$ & $0.010+M^{c}$ & $1584 \pm 45(5)$ & $0.030+M^{d}$ & $993 \pm 32(7)$ & $0.030+M^{e}$ & $385 \pm 48^{* * *}(40)$ \\
\hline & $0.060+M^{b}$ & $665 \pm 82^{*}(26)$ & $0.030+M^{c}$ & $1504 \pm 68(10)$ & $0.060+M^{d}$ & $958 \pm 20(10)$ & $0.060+M^{e}$ & $293 \pm 27^{* * *}(54)$ \\
\hline & $0.120+M^{b}$ & $632 \pm 54^{* *}(29)$ & $0.060+M^{c}$ & $1443 \pm 82(14)$ & $0.120+M^{d}$ & $864 \pm 39^{* *}(19)$ & $0.120+M^{e}$ & $253 \pm 19^{* * *}(60)$ \\
\hline & $0.250+M^{b}$ & $621 \pm 42^{* *}(30)$ & $0.120+M^{c}$ & $1409 \pm 72(16)$ & $0.250+M^{d}$ & $725 \pm 23^{* * *}(32)$ & $0.250+M^{e}$ & $148 \pm 23^{* * *}(77)$ \\
\hline & $M^{b}$ & $893 \pm 79$ & $M^{c}$ & $1672 \pm 102$ & $M^{d}$ & $1064 \pm 101$ & $M^{e}$ & $640 \pm 49$ \\
\hline
\end{tabular}

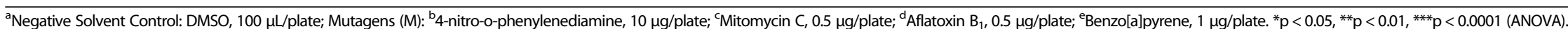


ratio of 20.4, suggesting that quercetin contributes to the mutagenic potential of this genus.

For the hydroalcoholic extract of $B$. intermedia and B. fagifolia, the results obtained here are also similar to results described for the $\mathrm{MeOH}$ extract $[5,17]$. This fact suggests that the $\mathrm{MeOH}$ and hydroalcoholic extracts are similar in composition.

The detection of genotoxicity is highly advisable, so as to avoid the risk of genotoxic exposure to mutagens and carcinogens. However, some genotoxic compounds cannot be completely avoided because they are air pollutants, or some might be ingested as food contaminants. Also, some therapeutic drugs belong to an important group of genotoxic compounds. Antimutagenicity studies have been developed to diminish the risk in the event of genotoxic exposure [18]. There have been several reports in the literature, that medicinal plants or fruit juices have components such as polyphenols, vitamins, chlorophylls, terpenes and unknown organic compounds, which are described as antimutagens and perhaps anticarcinogens [19].

In the present study, the B. verbascifolia and B. correifolia extracts acted as strong antimutagens against NPD, with inhibition up to $48 \%$ and $51 \%$ of induced revertants, respectively. B. fagifolia and B. intermedia were moderately antimutagenic, and their percentages of inhibition reached $36 \%$ and $30 \%$. These extracts were able to prevent frameshift mutations.

When combined with MMC, none of the extracts could be considered antimutagenic, although $B$. correifolia extract reduced significantly the number of revertants at several doses.

Against $\mathrm{AFB}_{1}$, B. verbascifolia and B. correifolia extracts performed as strong antimutagens, reaching inhibition levels of $91 \%$ and $80 \%$ of revertants, respectively. It should be emphasized that when the concentration of the $B$. verbascifolia extract was varied, the inhibition remained at $91 \%$, which reinforces its strongly protective potential. B. fagifolia and B. intermedia were moderately antimutagenic in these tests, reaching $36 \%$ and $32 \%$ inhibition, respectively. This demonstrates the potential of these extracts to be used as protective agents against indirect mutagens, which require metabolic activation.

Against B[a]P, all the extracts showed strong antimutagenicity and may be able to prevent frameshift mutations. B. verbascifolia reached a level of inhibition of $82 \%$, B. correifolia $83 \%$, B. fagifolia $76 \%$ and B. intermedia $77 \%$. It should be emphasized that even when the concentration of the B. correifolia extract was varied, the percentages of inhibition remained very close to each other (at 82-83\%), confirming its protective potential.

In previous studies, no mutagenic activity was observed in $\mathrm{MeOH}$ and chloroform extracts of B. basiloba, however, both extracts showed antimutagenic activity. The highest inhibition level (89\%) was obtained with the
$\mathrm{MeOH}$ extract, in the strain TA100 in the presence of $\mathrm{AFB}_{1}$. Phytochemical analysis of these extracts revealed the presence of $n$-alkanes, lupeol, ursolic and oleanolic acid, (+)-catechin, quercetin-3- $O-\alpha-{ }_{-}$-arabinopyranoside, gallic acid, methyl gallate, amentoflavone, quercetin, quercetin-3-O-(2"-O-galloyl)- $\beta$ - ${ }^{-}$-galactopyranoside, and quercetin-3-O-(2"-O-galloyl)- $\alpha-\mathrm{L}$-arabinopyranoside [6]

Rinaldo et al. [14] demonstrated that in $\mathrm{MeOH}$ extracts and aqueous infusions from the leaves of five Byrsonima species, only in B. coccolobifolia was it not possible to observe the presence of catechins and epicatechins. In the other four species analyzed, it was found that the $\mathrm{MeOH}$ extracts showed larger amounts of catechins than the infusions, per gram of leaves. B. basiloba showed the highest concentration of catechin diastereomers, followed by $B$. verbascifolia, $B$. crassa and B. intermedia.

The results of this study are in agreement with those in the above mentioned research. B. verbascifolia and $B$. intermedia did not exhibit mutagenic activity, nor $\operatorname{did} B$. basiloba [6], but all of them were antimutagenic and showed high concentrations of catechins [14], suggesting that catechins are important in antimutagenic activity. This point is corroborated by a study that claims that catechins are already known for their antimutagenic and cancer preventive properties [20,21].

The phytochemistry of all species analyzed to date in the genus Byrsonima is similar; we suggest that all species possess amentoflavone and quercetin, but in varied amounts. Probably, B. coccolobifolia and B. ligustrifolia possess higher concentrations of amentoflavone or quercetin, because they were mutagenic, but all the other species studied here probably possess a lower concentration of these flavonoids.

Although the mutagenic biflavonoid amentoflavone was present in the non-mutagenic B. basiloba, the amount of this compound found in the $\mathrm{MeOH}$ extract $(1.79 \mathrm{mg} / \mathrm{g}$ of $\mathrm{MeOH}$ extract) was much smaller than that found in the (mutagenic) B. crassa (17.04 $\mathrm{mg} / \mathrm{g}$ of $\mathrm{MeOH}$ extract) and B. intermedia $(13.70 \mathrm{mg} / \mathrm{g}$ of $\mathrm{MeOH}$ extract) extracts, which showed weak signs of mutagenicity in an earlier study $[5,6]$.

Finally, we have to emphasize the excellent chemopreventive ability of these extracts, especially with respect to compounds that require metabolic activation. All extracts evaluated were considered strongly antimutagenic against at least one of the tested mutagens.

The careful study of medicinal plants should be encouraged, because while many beneficial properties are confirmed or discovered, as shown here, some species may pose risks to users.

\section{Conclusion}

These results contribute valuable data on the safe use of medicinal plants and some benefits, such as chemopreventive 
effects. Some medicinal plants should be used with caution by the population, such as $B$. coccolobifolia and $B$. ligustrifolia, because they are mutagenic. However, $B$. verbascifolia, B. correifolia, B. fagifolia and B. intermedia were found to be strongly antimutagenic against at least one of the mutagens tested and, given the outstanding antimutagenic activities revealed in some tests, these extracts are good candidates for development as chemopreventive agents. Considering that medicinal herbs contain complex mixtures of thousands of components that can act alone or synergistically [22], it is important to continue phytochemical studies of hydroalcoholic extracts, to provide the chemical profile of the active species.

\section{Abbreviations}

NPD: 4- nitro-o-phenylenediamine; $\mathrm{NaN}_{3}$ : Sodium azide; MMC: Mitomycin C 2-AA: 2-anthramine; 2-AF: 2-aminofluorene; DMSO: Dimethylsulfoxide; NADP: Nicotinamide adenine dinucleotide phosphate sodium salt; $B[a]$ P: Benzo[a]pyrene; $\mathrm{AFB}_{1}$ : Aflatoxin $\mathrm{B}_{1} ;+\mathrm{S} 9$ : With metabolization; $-\mathrm{S} 9$ : Without metabolization; MR: Mutagenicity ratio; SD: Standard deviation.

\section{Competing interests}

The authors declare that they have no competing interests.

\section{Authors' contributions}

LGE designed and performed the experiments, interpreted the results and drafted the manuscript. FAR performed some experiments and interpreted some results. JSLN, WV and LCS prepared the hydroalcoholic extract of Byrsonima species. FAR, PKB and CHN participated in the assays of mutagenicity. FAR, MSC and RADG participated in the assays of antimutagenicity. FAR and EAV read the manuscript critically and participated in its revision. All authors have read and approved the final manuscript.

\section{Acknowledgments}

This study was supported by Fundação de Amparo à Pesquisa do Estado de São Paulo (FAPESP) and Conselho Nacional de Desenvolvimento Científico e Tecnológico (CNPq). We also thank Conselho Nacional de Desenvolvimento Científico e Tecnológico (CNPq) for grants to L.C. Santos, E.A. Varanda and W. Vilegas

\section{Author details}

'Department of Biological Sciences, Faculty of Pharmaceutical Sciences of Araraquara, UNESP- São Paulo State University, Rodovia Araraquara-Jaú, km 1, 14801-902 Araraquara, São Paulo, Brazil. 'Department of Organic Chemistry, Chemistry Institute of Araraquara, UNESP- São Paulo State University, Rua Francisco Degni s/n, Bairro Quitandinha, c.p. 355, 14800-900 Araraquara, São Paulo, Brazil. ${ }^{3}$ Campus do Litoral Paulista - Unidade São Vicente, UNESP-São Paulo State University, 11330-900 São Vicente, São Paulo, Brazil.

Received: 16 December 2013 Accepted: 29 May 2014

Published: 5 June 2014

\section{References}

1. De Pasquale A: Pharmacognosy: the oldest modern science. J Ethnopharmacol 1984, 11:1-16.

2. Mendanha DM, Ferreira HD, Felício LP, Silva EM, Pereira DG, Nunes WB, Carvalho S: Modulatory effect of Byrsonima verbascifolia (Malpighiaceae) against damage induced by doxorubicin in somatic cells of Drosophila melanogaster. Genet Mol Res 2010, 9:69-77.

3. Guilhon-Simplicio F, Pinheiro CCS, Contado GG, Barbosa GS, Dos Santos PA, Pereira MM: Anti-inflammatory, anti-hyperalgesic, antiplatelet and antiulcer activities of Byrsonima japurensis A. Juss. (Malpighiaceae). J Ethnopharmacol 2012, 140:282-286.
4. Cardoso CRP, Cólus IMS, Bernardi CC, Sannomiya M, Vilegas W, Varanda EA Mutagenic activity promoted by amentoflavone and methanolic extract of Byrsonima crassa Niedenzu. Toxicology 2006, 225:55-63.

5. Sannomiya M, Cardoso CRP, Figueiredo ME, Rodrigues CM, Dos Santos LC, Dos Santos FV, Serpeloni JM, Cólus IMS, Vilegas W, Varanda EA: Mutagenic evaluation and chemical investigation of Byrsonima intermedia A. Juss. leaf extracts. J Ethnopharmacol 2007, 112:319-326.

6. Lira WM, Dos Santos FV, Sannomiya M, Rodrigues CM, Vilegas W, Varanda EA: Modulatory effect of Byrsonima basiloba extracts on the mutagenicity of certain direct and indirect-acting mutagens in Salmonella typhimurium assays. J Med Food 2008, 11:111-119.

7. Mortelmans K, Zeiger E: The Ames Salmonella/microsome mutagenicity assay. Mutat Res 2000, 455:29-60.

8. Maron DM, Ames BN: Revised methods for the Salmonella mutagenicity test. Mutat Res 1983, 113:173-215.

9. Resende FA, Barbosa LC, Tavares DC, De Camargo MS, Rezende KCS, Silva MLA, Varanda EA: Mutagenicty and antimutagenicty of (-)-hinokin a trypanosomicidal compound measured by Salmonella microsome and comet assays. BMC Complement Altern Med 2012, 12:1-10.

10. Bernstein L, Kaldor J, Mccann J, Pike MC: An empirical approach to the statistical analysis of mutagenesis data from the Salmonella test. Mutat Res 1982, 97:267-281.

11. Tachino N, Guo D, Dashwood WM, Yamane SH, Larsen R, Dashwood R: Mechanisms of the in vitro antimutagenic action of chlorophyllin against benzo[a]pyrene: Studies of enzyme inhibition, molecular complex formation and degradation of the ultimate carcinogem. Mutat Res 1994, 308:191-203.

12. Neigi PS, Jayaprakasha GK, Jena BS: Antioxidant and antimutagenic activities of pomegranate peel extracts. Food Chem 2003, 80:393-397.

13. Vargas VMF, Motta VEP, Henriques JAP: Mutagenic activity detected by the Ames test in river water under the influence of petrochemical industries. Mutat Res 1993, 319:31-45.

14. Rinaldo D, Batista JM Jr, Rodrigues J, Benfatti AC, Rodrigues CM, Dos Santos LC, Furlan M, Vilegas W: Determination of Catechin Diastereomers from the leaves of Byrsonima species using Chiral HPLC-PAD-CD. Chirality 2010, 22:726-733.

15. Sannomiya M, Rodrigues CM, Coelho RG, Dos Santos LC, Hiruma-Lima CA, Brito ARMS, Vilegas W: Application of preparative high-speed countercurrent chromatography for the separation of flavonoids from the leaves of Byrsonima crassa Niedenzu (IK). J Chromatogr 2004, 1035:47-51.

16. Resende FA, Vilegas W, dos Santos LC, Varanda EA: Mutagenicity of Flavonoids assayed by bacterial reverse mutation (Ames) test. Molecules 2012, 17:5255-5268.

17. Lima ZP, Dos Santos RC, Torres TU, Sannomiya M, Rodrigues CM, dos Santos LC, Pellizzon CH, Rocha LRM, Vilegas W, Brito ARMS, Cardoso CRPC, Varanda EA, de Moraes HP, Bauab TM, Carli C, Carlos IZ, Hiruma-Lima CA: Byrsonima fagifolia: an integrative study to validate the gastroprotective healing, antidiarrheal, antimicrobial and mutagenic action. J Ethnopharmacol 2008, 120:149-160.

18. Arriaga-Alba M, Ruiz-Pérez NJ, Sánchez-Navarrete J, De Angel BL, Flores-Lozada J, Blasco JL: Antimutagenic evaluation of vitamins B1, B6 and B12 in vitro and in vivo, with the Ames test. Food Chem Toxicol 2013, 53:228-234.

19. Arriaga-Alba M, Blasco JL, Ruiz-Perez NJ, Sánchez-Navarrete J, RiveraSanchez R, Gonzalez-Avilla M: Antimutagenicity mechanisms of the Rhoeo discolor ethanolic extract. Exp Toxicol Pathol 2011, 63:243-248.

20. Baumeister P, Reiter M, Harréus U: Curcumin and other polyphenolic compounds in head and neck cancer chemoprevention. Oxid Med Cell Longev 2012, 2012:902716.

21. Xu G, Ren G, Xu X, Yuan H, Wang Z, Kang L, Yu W, Tian K: Combination of curcumin and green tea catechins prevents dimethylhydrazine-induced colon carcinogenesis. Food Chem Toxicol 2010, 48:390-395.

22. Boldrin PK, Resende FA, Höhne APO, de Camargo MS, Espanha LG, Nogueira $\mathrm{CH}$, Melo MSF, Vilegas W, Varanda EA: Estrogenic and mutagenic activities of Crotalaria pallida measured by recombinant yeast assay and Ames test. BMC Complement Altern Med 2013, 13:216.

doi:10.1186/1472-6882-14-182

Cite this article as: Espanha et al:: Mutagenicity and antimutagenicity of six Brazilian Byrsonima species assessed by the Ames test. BMC Complementary and Alternative Medicine 2014 14:182. 